\author{
콩과목초의 사초 수량 및 품질 비교 \\ 김종덕* · 김수곤** · 권찬호* \\ 천안연암대학*, 서울대학교 농생명공학부**
}

\title{
Comparison of Forage Yield and Quality of Forage Legume
}

\author{
J. D. Kim*, S. G. Kim** and C. H. Kwon*
}

Cheonan Yonam College, School of Agric. Biotechnol.*, Seoul National University**

\begin{abstract}
Forage legumes are being used as an important source of protein for dairy farm as well as nitrogen fertilizer. This experiment was conducted to evaluate forage production and quality of five legumes at Cheonan Yonam College Experimental Livestock Farm for 1 year(2001 J02). Five legumes were crimson clover (Trifolium incarnatum L.) 'Tibbee', hairy vetch(Vicia villosa Roth) 'Common', red clover(Trifolium pratense L.) 'Kenland', persian clover(Trifolium resupinatum L.) 'Leeton', alfalfa(Medicago sativa L.) 'Vernal'. All legumes were shown cold hardiness of 8 rating or higher except crimson clover(7 rating). Flowering stage was observed 23th of April for crimson clover, 13th of May for hairy vetch, 3rd of May for red clover, and 12th of May for alfalfa. But persian clover didn't at harvest. Dry matter(DM) of crimson clover(17.6\%) was the highest among legumes. In DM and total digestible nutrients(TDN) yields, crimson clover and hairy vetch were higher than those of other legumes. The crude protein of hairy vetch(20.5\%) was the highest among legumes. In neutral detergent fiber(NDF) and acid detergent fiber(ADF), persian clover was the lowest(35.0\% and 25.0\%). Calculations of relative feed value(RFV) based on NDF and ADF of legumes were over 125(Prime degree) except hairy vetch. RFV and TDN of persian clover were the highest among legumes. According to the results of this study, crimson clover and hairy vetch are excellent in forage yield. Persian clover is superior in forage quality among legumes.
\end{abstract}

(Key words : Legume, Cold hardiness, Forage yield, Forage quality)

\section{$\mathrm{I}$ 서 론}

콩과목초는 질소를 고정하는 능력이 있어 토 양에 질소를 공급하고(Hargrove, 1986), 식물체 는 단백질 함량이 높아 단백질 사료로 이용할 수 있어 여름작물인 옥수수나 수단그라스의 2 모작 작부체계에 이용할 수 있다(Burton, 1976; Utley 등, 1977; 김 등, 1997; 김 등, 2002).

크림손 클로버(Trifolium incarnatum L.)는 녹 비작물이나 단백질 사료로 이용하는 목초이며, 특히 우리나라에서 콩과목초 중에서 가장 일찍 개화하여 옥수수나 수수류의 전작물로 이용 가 능하다고 하였다(김 및 김, 1993; 김, 1986; 김
등, 1999; 김 등, 2002). 크림손 클로버는 유식 물 활력이 좋고 초기생육이 좋으며, 다양한 토 양에 잘 적응한다. 크림손 클로버의 수확적기 는 개화초기이며 이때는 품질이 좋으나 수확시 기가 늦어지면 줄기와 잎의 솜털이 굳어져서 기호성이 떨어진다(김, 1986; Hoveland 및 Evers, 1995).

헤어리 베치(Vicia villosa Roth)는 클로버류 보다 종자가 커서 파종 작업이 쉽고, 생육이 빠르며 생산량도 많아 녹비 및 청예작물로 적 합하다(서 등, 2000). 특히 헤어리 베치는 질소 고정능력이 우수하여 질소의 생산량이 350 $\mathrm{kgN} / \mathrm{ha}$ 까지 생산이 가능하다고 하였다(Power

Corresponding author : J. D. Kim, Cheonan Yonam College, Sunghwan, Cheonan-Si 330-802, Korea Tel : 041-580-1088, Fax : 041-580-1249, E-mail : yasc@yonam.ac.kr 
and Zachariassen, 1993).

레드 클로버(Trifolium pratense L.)는 기온이 온화하고 습윤한 지역에 잘 재배되는 단년생 콩과목초로 청예, 건초, 사일리지, 방목용으로 이용된다. 콩과목초 중에서 수량이 높은 목초 중의 하나이며, 단백질 함량과 기호성이 높은 우량한 목초이다(김 등, 2002).

페르시안 클로버(Trifolium resupintum L.)는 유식물 활력이 좋고 근류형성도 잘하는 목초로 $\mathrm{pH} 6.4$ 이상의 토양에 잘 자란다. 특히 페르시 안 클로버는 줄기가 비어 있어 건초로 적합하 다(Knight, 1985; 김 등, 2002).

이상의 콩과목초 4초종은 옥수수나 수수의 전작물이나 논에서 답리작으로 재배하여 토양 의 비옥도 증진이나 단백질 사료로 가능한 작 물이다. 그리고 앞서 언급한 4초종이 미국에서 도 남부지방에서 이용하는 작물이고 내한성도 약한 초종이므로 우리나라의 중부지방에서 재 배 가능한 작물인지의 검토가 필요하였다. 또 한 각 초종의 사초 생산성과 품질을 비교함으 로써 낙농가의 재배 이용에 도움을 주고자 한 다. 따라서 본 시험에서는 콩과목초 5 초종을 충남 천안에서 파종하여 생육특성, 사초 생산 성 및 품질을 비교하였다.

\section{재료 및 방법}

본 시험은 천안연암대학 실습농장의 사초시 험 포장에서 콩과목초를 파종하여 생산성을 비교하였다. 시험설계는 5초종을 처리로 하고 3 반복을 한 난괴법 배치로 비교시험을 실시하 였다. 공시초종 및 품종은 크림손 클로버 (Trifolium incarnatum L.) 'Tibbee', 헤어리 베치 (Vicia villosa Roth) 'Common', 레드 클로버 (Trifolium pratense L.) 'Kenland', 페르시안 클로 버(Trifolium resupinatum L.) 'Leeton', 알팔파 (Medicago sativa L.) 'Vernal'를 공시하였다. 파 종시기는 2001년 8월 23일에 파종하였으며, 수 확일은 월동후 이듬해인 5월 13 일에 수확하였 다.

시험구 크기는 $6 \mathrm{~m}^{2}(4 \mathrm{~m} \times 1.5 \mathrm{~m})$ 로 파종량은 ha당 $30 \mathrm{~kg}$ 를 산파하였다. 시비량은 ha당 질소
$30 \mathrm{~kg}$, 인산 $150 \mathrm{~kg}$ 및 칼리 $80 \mathrm{~kg}$ 을 각각 파종일 에 전량 시비하였다.

충남 천안의 온도 및 강수량은 Table 1 에서 보는 바와 같다. 먼저 온도는 예년에 비하여 1.9도 낮았다. 강수량은 예년보다 적었으나. 월 동후 4월 이후에는 비가 많았다.

Table 1. Mean temperature and precipitation at Cheonan, 2001 to 2002

\begin{tabular}{lrrrrrr}
\hline \multirow{2}{*}{ Month } & \multicolumn{2}{c}{ Temperature $\left({ }^{\circ} \mathrm{C}\right.$} & & \multicolumn{2}{c}{ Precipitation(mm) } \\
\cline { 2 - 3 } \cline { 5 - 6 } & '01 & 2 Normal & & '01 2 & Normal \\
\hline \hline August & 17.2 & 23.7 & & 1.0 & 108.3 \\
September & 13.6 & 19.8 & & 12.0 & 137.9 \\
October & 7.8 & 13.1 & & 63.5 & 58.5 \\
November & -1.6 & 6.1 & & 6.3 & 52.9 \\
December & -2.0 & -0.1 & & 18.4 & 29.1 \\
January & 0.0 & -3.0 & & 45.3 & 24.0 \\
February & 0.2 & -0.8 & & 6.0 & 27.7 \\
March & 6.3 & 4.4 & & 25.5 & 48.4 \\
April & 13.1 & 11.3 & & 128.0 & 78.9 \\
May & 16.0 & 15.5 & & 91.0 & 31.8 \\
\hline Mean & 7.1 & 9.0 & Sum & 397.0 & $1,089.9$ \\
\hline
\end{tabular}

콩과목초의 유식물 활력, 내한성 및 내도복 성은 1 에서 9 점으로 점수를 주어 아주 약한 경 우 1 로 하고 아주 강한 경우 9 로 점수를 매겨 유식물 활력은 생육초기, 내한성은 월동후 3월 15일, 내도복성은 수확시에 조사하였다. 건물 률, 건물수량 및 품질을 비교하기 위하여 수확 시에 시험구당, 600 $00 \mathrm{~g}$ 의 시료를 채취하여 $65^{\circ} \mathrm{C}$ 순환식 열풍건조기에서 5 일간 건조하였 다. 시료는 전기믹서로 1 차 분쇄한 후 20 mesh Wiley Mill로 2차 분쇄하여 분석에 사용하였다.

NDF(Neutral detergent fiber) 및 ADF(Acid detergent fiber)는 Goering 및 Van Soest 방법(1970) 으로 분석하였다. 조단백질 분석은 Kjeldahl법 (Tecator, Kjeltec Auto Sampler System 1035 Analyzer)을 사용하여 AOAC 법(1990)으로 분석 하였다.

$\mathrm{TDN}$ 수량은 $\mathrm{TDN}=88.9-(0.79 \times \mathrm{ADF} \%)$ 에 의하여 TDN을 산출한 후 건물수량을 곱하여 
구하였으며, RFV(relative feed value)는 $\mathrm{ADF}$ 와 $\mathrm{NDF}$ 가 건물소화율 및 섭취량과 높은 상관관계 를 가진다는 점에 근거하여 $\mathrm{ADF}$ 와 $\mathrm{NDF}$ 분석 치에 의한 계산식으로 산출하였다(Holland 등, 1990).

통계처리는 SAS(1999) package(ver. 6.12)을 이용하여 분산분석을 실시하였으며, 처리평균 간 비교는 최소유의차(LSD) 를 이용하였다.

\section{III 결과 및 고찰}

\section{1. 콩과목초의 생육특성}

콩과목초의 생육특성은 Table 2에서 보는 바 와 같다. 유식물 활력은 크림손 클로버와 페르 시안 클로버가 9점으로 우수하였으며, 다년생 인 알팔파는 7점으로 가장 낮았다. 반면 콩과 목초의 내한성은 크림손 클로버가 공시초종 중 에서 가장 낮고, 알팔파가 9점으로 가장 높았 다. 크림손 클로버는 내한성이 약하여 우리나 라의 남부지방에만 이용이 가능하다고 하였으 나(김, 1986), 1990 년 이후의 김 및 김(1993)과 김 등(1997)의 시험에서는 중부지방에서 월동을 하였으며, 본 시험에서도 내한성은 공시초종 중에서 가장 낮았으나 월동후 생육에는 큰 영 향이 없었다.

콩과목초의 개화일은 크림손 클로버가 4월 23일로 가장 먼저 개화하였으며, 다음은 레드 클로버로 5월 3일에 개화하였다. 김 등(1999) 의 시험에서도 크림손 클로버는 5월 7 일에 개
화를 하였으나 레드 클로버와 알팔파는 수확시 까지 개화를 하지 않았다. 본 시험에서는 페르 시안 클로버를 제외하고는 모두 5월 초까지 개 화를 하여 옥수수와 수단그라스와 2모작이 가 능한 초종으로 평가되었다. 페르시안 클로버의 품종들은 수확시까지 개화를 하지 않아 공시초 종 중에서 가장 숙기가 느린 초종이었다. 김 등(2002)의 시험에서도 페르시안 클로버는 개화 를 하지 않아 본 시험과 같은 경향을 보였다.

콩과목초의 내도복성은 다년생인 알팔파와 2 년생 레드 클로버가 가장 높았으며, 헤어리 베 치는 내도복성이 가장 낮았다. 이는 헤어리 베 치의 초장이 공시품종 중에서 가장 높고, 초형 이 넝쿨성인 것이 원인으로 생각된다. 따라서 헤어리 베치는 직립형인 화본과 파종하여 이용 하는 것이 좋을 것으로 판단되었다.

\section{2. 콩과목초의 사초생산성 및 품질}

수확시 건물률은 Table 3에서 보는 바와 같 이 숙기가 가장 빠른 크림손 클로버와 다년생 인 알팔파가 $17.6 \%$ 로 가장 높았으며, 수확시까 지 출수를 하지 않은 페르시안 클로버는 $10.2 \%$ 로 건물률이 가장 낮았다 $(\mathrm{P}<0.05)$. 그러나 페 르시안 클로버는 berseem clover와 같이 줄기가 비어 있어 건초제조시 줄기 건조속도가 빨라 고품질의 건초를 제조할 수 있을 것으로 생각 된다.

건물수량은 Table 3 에서 보는 바와 같이 크 림손 클로버와 헤어리 베치가 각각 9,050 와

Table 2. Agronomic characteristics of five legumes at Cheonan, 2001 to 2002

\begin{tabular}{lccccc}
\hline Species & Seedling vigor & Cold hardness & Flowering stage & Lodging resistance & Plant height \\
\hline Crimson clover & 9 & $-(1-9)-$ & - Date - & $-(1-9)-$ & $-\mathrm{cm}-$ \\
Hairy vetch & 8 & 7 & 23 April & 7 & 92 \\
Red clover & 8 & 9 & 13 May & 7 & 111 \\
Persian clover & 9 & 8 & 3 May & 9 & 83 \\
Alfalfa & 7 & 8 & - & 8 & 64 \\
\hline Mean & 8 & 9 & 12 May & 9 & 76 \\
\hline
\end{tabular}

Rating : 9 = outstanding, 1 = poor. 
Table 3. Forage production of five legumes at Cheonan, 2001 to 2002

\begin{tabular}{lccc}
\hline Species & $\begin{array}{c}\text { Dry } \\
\text { matter }\end{array}$ & $\begin{array}{c}\text { DM } \\
\text { yield }\end{array}$ & $\begin{array}{c}\text { TDN } \\
\text { yield }\end{array}$ \\
\hline \hline Crimson clover & 17.6 & 9,050 & 5,486 \\
Hairy vetch & 13.6 & 9,117 & 5,023 \\
Red clover & 16.0 & 5,212 & 3,438 \\
Persian clover & 10.2 & 5,440 & 3,762 \\
Alfalfa & 17.6 & 5,841 & 3,795 \\
\hline Mean & 15.0 & 6,932 & 4,301 \\
LSD(0.05) & 1.3 & 813 & 482 \\
\hline
\end{tabular}

$9,117 \mathrm{~kg} / \mathrm{ha}$ 로 다른 초종보다 많았으며, 다음 으로 다년생인 알팔파로 $5,841 \mathrm{~kg} / \mathrm{ha}$ 이었다. 그리고 크림손 클로버와 헤어리 베치를 제외 한 콩과목초도 건물수량이 5 톤/ha 이상으로 높아 천안에서 생산성이 높은 초종으로 평가 되었다.

콩과목초의 TDN 수량은 건물수량과 마찬 가지로 크림손 클로버와 헤어리 베치가 각 각 5,486 및 $5,023 \mathrm{~kg} / \mathrm{ha}$ 로 다른 초종보다 많 았다.

서 등(2000)은 헤어리 베치를 비롯한 콩과목 초의 수량을 비교한 시험에서 헤어리 베치가 레드 및 크림손 클로버보다 건물수량이 많았으 나 본 시험보다는 콩과목초의 건물 수량이 적 었다. 김 등(1999), 서 등(2000) 및 김 등(2002) 을 비교할 때 콩과목초는 년도와 수확시기에 따라 수량의 차이가 많았다. 따라서 콩과목초 는 생육후기에 수량이 많이 증가함으로 5월 15 일 이후에 수확하는 것이 좋을 것으로 생각된 다.

천안에서 수확한 콩과목초의 품질은 Table 4 에서 보는 바와 같다. 먼저 조단백질 함량은 숙기가 늦은 헤어리 베치가 $20.5 \%$ 로 가장 높았 으며, 페르시안 클로버는 $17.0 \%$ 로 다음으로 높 았다. 한편 크림손 클로버는 $10.7 \%$ 로 공시초종 중에서 가장 낮았다. 김 등(1999)의 시험에서는 크림손 클로버의 조단백질 함량이 레드 클로버 와 알팔파보다 낮았으며, 김 등(2002)의 시험에
Table 4. Forage quality of five legumes at Cheonan, 2001 to 2002

\begin{tabular}{|c|c|c|c|c|c|}
\hline Species & $\mathrm{CP}$ & NDF & $\mathrm{ADF}$ & RFV & TDN \\
\hline & \multicolumn{3}{|c|}{$\ldots \ldots \ldots \%$} & & $\%$ \\
\hline Crimson clover & 10.7 & 44.7 & 35.8 & 127 & 60.6 \\
\hline Hairy vetch & 20.5 & 49.6 & 42.8 & 104 & 55.1 \\
\hline Red clover & 13.8 & 47.6 & 29.0 & 130 & 66.0 \\
\hline Persian clover & 17.0 & 35.0 & 25.0 & 185 & 69.2 \\
\hline Alfalfa & 16.0 & 41.1 & 34.4 & 141 & 61.7 \\
\hline Mean & 15.6 & 43.6 & 33.4 & 137 & 62.5 \\
\hline LSD(0.05) & 5.2 & 4.5 & 3.2 & 18 & 4.3 \\
\hline
\end{tabular}

서는 페르시안 클로버는 공시초종 중에서 조단 백질 함량이 높아 본 시험과 같은 경향이었다. 이상의 단백질 함량을 볼 때 헤어리 베치는 토 양의 질소고정 능력 우수할 뿐만아니라 식물체 내 단백질 함량도 우수한 것으로 판단된다. 서 등(2000)의 시험에서도 헤어리 베치가 레드 및 크림손 클로버보다 식물체 질소 함량이 높았다 고 보고하여 본 시험과 같은 경향이었다.

$\mathrm{NDF}$ 및 $\mathrm{ADF}$ 함량은 헤어리 베치가 $49.6 \%$ 및 42.8\%로 공시초종 중에서 가장 높아 품질이 낮았으며, 페르시안 클로버는 $35.0 \%$ 및 $25.0 \%$ 로 가장 낮아 품질이 우수한 것으로 평가되었 다.

$\mathrm{ADF}$ 와 $\mathrm{NDF}$ 함량을 근거로 추정 계산한 상 대사료가치(RFV)는 페르시안 클로버가 185 였으 며, $\mathrm{NDF}$ 와 $\mathrm{ADF}$ 가 낮은 헤어리베치는 104이었 다. 그러나 공시초종 모두가 상대사료가치가 100 이상으로 양질의 사초였다. 김 등(1999)의 시험에서는 콩과목초의 상대사료가치가 164 였 으며, 크림손 클로버는 126으로 본 시험보다 높았다. 이는 본 시험이 김 등(1999) 보다 늦은 시기에 수확한 것이 원인인 것으로 생각된다. 이상의 상대사료가치는 다른 시험(김 및 김, 1993; 김 등, 1999; 신, 1999; 신 등, 2000; 김 등, 2002) 보다 낮았으나 미국의 사초등급 (AFGC)에 의하면 공시품종 모두가 1 등급 이상 으로 우수하였다(Balyor, 1991).

이상의 결과를 종합해 볼 때 콩과목초는 페 
르시안 클로버와 알팔파를 제외하고는 5월초까 지 개화하여 옥수수 또는 수단그라스와 2모작 이 가능한 콩과목초로 평가되었다. 특히, 크림 손 클로버와 헤어리 베치는 건물 및 $\mathrm{TDN}$ 수량 이 우수한 작물이었다. 한편 페르시안 클로버 는 사초품질이 우수하였다.

$$
\text { IV 요 약 }
$$

콩과목초는 젖소의 중요한 단백질 공급원이 며 토양에는 질소비료원이다. 본 시험은 콩과 목초의 사초생산성과 품질을 비교하기 위하여 천안연암대학의 실습농장에서 실시하였다. 공 시한 콩과목초 5초종은 2모작이 가능한 목초로 크림손 클로버(Trifolium incarnatum L.) 'Tibbee', 헤어리 베치(Vicia villosa Roth) 'Common', 레드 클로버(Trifolium pratense L.) 'Kenland', 페르시 안 클로버(Trifolium resupinatum L.) 'Leeton', 알 팔파(Medicago sativa L.) 'Vernal' 이다. 콩과목 초의 내한성은 크림손 클로버가 7점인 것을 제 외하고는 공시품종 모두가 8점 이상으로 양호 하였다. 콩과목초의 개화기는 크림손 클로버가 4월 23일로 공시초종 중에서 가장 빨리 개화 하였으며, 헤어리 베치는 5월 13일, 레드 클로 버는 5월 3일, 알팔파는 5월 12 일에 개화하였 다. 그러나 페르시안 클로버는 수확시까지 출 수를 하지 않았다. 수확시 건물률은 크림손 클 로버가 $17.6 \%$ 로 공시초종 중에서 가장 높았 다. 건물 및 $\mathrm{TDN}$ 수량은 크림손 클로버와 헤 어리 베치가 공시초종 중에서 가장 많았다. 조 단백질 함량은 헤어리 베치가 20.5\%로 가장 높았다. $\mathrm{NDF}$ 및 $\mathrm{ADF}$ 함량은 페르시안 클로버 가 35.5 및 $25.0 \%$ 로 가장 적었다. $\mathrm{NDF}$ 와 $\mathrm{ADF}$ 를 근거로 계산한 상대사료가치(RFV)는 헤어 리 베치를 제외하고는 콩과목초 모두가 125이 상으로 특급이었다. 페르시안 클로버는 공시초 종에서 상대사료가치와 $\mathrm{TDN}$ 이 가장 높은 양 질의 콩과목초였다. 이상의 결과를 종합해 볼 때 콩과목초 중 크림손 클로버와 헤어리 베치 가 사초수량이 높았고, 페르시안 클로버가 품 질이 우수하였다.

\section{$\mathrm{V}$ 사 사}

본 연구는 농림부 농림기술관리센터의 연구 비 지원의 일부에 의해 수행된 것으로, 이에 감사를 드립니다.

\section{$\mathrm{VI}$ 인 용 문 헌}

1. AOAC. 1990. Official Method of Analysis(15th ed.). Association of Official Analytical Chemists. Washington, D. C.

2. Baylor, J. E. 1991. Hay management in North America. In Field guide for hay and silage management. Bolsen, K. K., Baylor, J. E. and McCullough, M. E. 1991. National Feed Ingredients Association.

3. Burton, G. W. 1976. Legume nitrogen versus fertilizer nitrogen for warm-season grasses. In Hovelans, C. S.(ed.) Biological N Fixations in Forage-livestock System. Spec. Publ. 28. ASA, Madison, WI. p. 55-81.

4. Goering, H. L. and Van Soest, P. J. 1970. Forage Fiber Analysis. Agr. Handbook No. 379. USDA.

5. Hargrove, W. L. 1986. winter legumes as a nitrogen source for no-till grain sorghum. Agron. J. 78: 70-74.

6. Hoveland, C. S. and Evers, G. W. 1995. Arrowleaf, crimson clover, and other annual clovers. In Barnes, R. F. Miller, D. A. and Nelson, C. J.(ed.) Forage(volume I : An Introduction to Grassland Agriculture. Iowa State University Press. Ames, Iowa. pp. 249-260.

7. Knight, W. E. 1985. Miscellaneous annual clovers. In Taylor, N. L. (ed.), Clover Science and Technology. Am. Soc. Agron. Monogr. 25. Madison, WI. pp. 547-562.

8. Power, J. F. and Zachariassen, J. A. 1993. Relative nitrogen utilization by legume cover crop species at three soil temperature. Agron. J. 85:134-140.

9. SAS Institute, Inc. 1999. SAS user's guide : Statistics. SAS Inst., Inc., Cary, NC.

10. Utley, P. R., Marchant, W. H. and McCormick, W. C. 1977. Dixie crimson and Amclo arrowleaf clovers as pastures for growing steers. Georgia Agri. Res. 18(4) : 21-23.

11. 김동암, 김원호. 1993. 추파사료작물이 사일리지 용 옥수수의 생장, 수량 및 사료가치에 미치는 영향. 한초지 13(2):122-131.

12. 김동암, 김종덕, 이광녕, 신동은, 정재록, 김원호. 1997. 콩과목초 잔주의 사일리지용 옥수수에 대 한 질소공급효과. 한초지 17(3):293-304.

13. 김동암, 김종덕, 한건준, 이광녕, 김종근. 1999. 
봄철 포장건조 콩과목초의 수량 및 품질 손실. 한초지 19(2):127-132.

14. 김동암. 1986. 사료작물: 그 특성과 재배방법. 선 진문화사. 서울.

15. 김종덕, 권찬호, 김수곤, 박형수, 고한종, 김동암. 2002. 중부지방에서 일년생 콩과목초의 사초생산 성 비교. 동물자원지 44(5):617-624.

16. 서종호, 이호진, 허일봉, 김시주, 김충국, 조현숙.
2000. 동계 녹비작물 초종별 화학성분 및 생산성 비교. 한초지 20(3):193-198.

17. 신정남. 1999. 야생 알팔파의 건물수량, 생육특성 및 사료적인 가치. 한초지 19(2):159-166.

18. 신정남, 김동암, 고기환, 김용원. 2000. 도입베치 품종 및 한국 야생종의 생육특성과 수량. 한초지 20(4):251-258.

(접수일자 : 2004. 1. 7. / 채택일자 : 2004. 5. 11.) 